\title{
Evaluation of Zeolitic Materials Synthetized from Coal Fly Ash as Potential Cd(II) Adsorbents from Aqueous Solutions
}

\author{
CLAUDIA MARIA SIMONESC ${ }^{1 *}$, ALINA MELINESCU ${ }^{2 *}$, DANIELA CRISTINA CULITA ${ }^{3}$, \\ DHUHA HASAN ${ }^{1}$, BIANCA ZARNESCU ${ }^{1}$, MARIA CIUCA ${ }^{1}$ \\ ${ }^{1}$ University Politehnica of Bucharest, Faculty of Applied Chemistry and Materials Science, Department of Analytical \\ Chemistry and Environmental Engineering, 1-7 Polizu Str., 011061, Bucharest, Romania \\ ${ }^{2}$ University Politehnica of Bucharest, Faculty of Applied Chemistry and Materials Science, Department of Department of \\ Science and Engineering of Oxide Materials and Nanomaterials, 1-7 Polizu Str., 011061, Bucharest, Romania \\ ${ }^{3}$ Ilie Murgulescu Institute of Physical Chemistry, 202 Splaiul Independentei, 060021, Bucharest, Romania
}

\begin{abstract}
The aim of this research paper is to present a simple and efficient method to prepare zeolite materials from thermal power plant fly ash which is one of the most important waste resulted from power plants. The method of preparation of zeolite materials consists of alkaline activation followed by calcination at different temperatures. The zeolite materials prepared were studied by FT-IR spectroscopy, specific surface determination, $X$-ray fluorescence spectroscopy $(X R F)$, scanning electron microscopy (SEM) and particle size composition. XRF data indicated that the zeolites synthesized are characterized by Si/Al ratio between 1.21 and 1.26, being mainly composed of Na-P1 zeolite. The optimum conditions of cadmium ions removal process by adsorption onto zeolite materials have been determined. It was concluded that increase of calcination temperature has as result increase of specific surface area and cosequently the increase of sorption capacity. An equilibrium, kinetic and thermodynamic study has been performed. The high value of correlation coefficient for the Langmuir isotherm reveals that the Cd(II) sorption onto zeolite materials occurs as a monolayer coverage of Cd(II) ions on homogenous zeolite surface. The pseudo-second-order kinetic model fits the experimental results of the Cd(II) sorption onto zeolite materials processes. As a results, the mechanism involved in Cd(II) sorption onto zeolite materials is based on chemical reactions. The thermodynamic results indicate that the Cd(II) adsorption process is more encouraging at higher temperatures. The results established that valuable NaPl zeolite materials with high adsorption capacity can be prepared from thermal power plant fly ash through a simple method. The materials prepared can be utilized to remediate cadmium ions-bearing wastewater.
\end{abstract}

Keywords: thermal power plant fly ash, zeolite materials, cadmium pollution, cadmium removal

\section{Introduction}

Heavy metal contamination is an anthropogenic and natural inevitable issue that people have struggled to deal with. As it is known, heavy metals are not biodegradable and they are bioaccumulated through all the levels of trophic chain having negative effects to all the living organisms [1]. Even at low level, almost all heavy metals are toxic to human beings [2-16]. The main anthropogenic sources of heavy metals are wastewater from industries such as: mining, plating, metal-finishing, electronic, metallurgical, fertilizers, synthetic chemicals, pulp and paper, pesticides, tanning, pigments, rubber and plastics, batteries and petroleum products [2-16].

Among the heavy metals, cadmium is one of the most toxic heavy metals that once entered into the human body, it is bound firmly to metallothioneins [2]. Over half, $\mathrm{Cd}(\mathrm{II})$ in the human body accumulates in the liver and kidney causing liver harm, bone degeneration, blood damage, and renal dysfunction [2].

Due to the negative effects of the heavy metals to aquatic ecosystems and human beings, most of the countries have imposed strict norms for heavy metals allowable limits. To reach these limits, the traditional physical-chemical and unconventional methods have been applied to remediate wastewater and polluted environments.

$\overline{\text { *email: claudiamaria_simonescu@yahoo.com; alina.melinescu@gmail.com }}$ 
The different traditional remediation methods available for removal of toxic heavy metals from the water/wastewater include chemical precipitation, chemical coagulation and flocculation, electrochemical processes, ion exchange, membrane filtration, and adsorption [1, 2-16]. In the category of unconventional methods can be mentioned biosorption and bioremediation.

Fly ash as a coal combustion by-product is generated in large amounts from coal thermal power plant around the world [17]. Consequently, numerous environmental issues are generated due to the increasing amount of waste material that has to be disposed in landfills. Its composition and properties make a good material for agricultural applications, cement and concrete industries, soil stabilization, for reinforcing filler in polymers, environment remediation and zeolite synthesis [17, 18]. Of these applications, zeolites synthesis is of great interest due to the fact that zeolites have wide industrial applications [19]. Furthermore, zeolites sale can offset the flys ash disposal costs as well as overcoming environmental problems [19].

Zeolites are crystalline aluminum-silicates, with group I or II elements as counterions [20]. Their structure consists of a framework of $\left[\mathrm{SiO}_{4}\right]^{4}$ - and $\left[\mathrm{AlO}_{4}\right]^{5}$ - tetrahedra linked to each other at the corners by sharing their oxygen atoms [20]. The arranging of tetrahedra in the zeolite's structure leads to a threedimensional network with numerous voids and open spaces. This structure defines the particular properties of zeolites, like adsorption of molecules [20]. The main structural and valuable properties of zeolites determined widespread application in ion exchange, molecular sieve and adsorption.

Many different types of zeolites can be prepared from fly ash by varying synthesis conditions. The conversion of fly ash into zeolites is considered one of the most important issues of waste management. All the methods used to prepare zeolites from fly ash are based on the dissolution of Al-Si-bearing fly ash phases with alkaline solutions (mainly $\mathrm{NaOH}$ and $\mathrm{KOH}$ solutions) and the subsequent precipitation of zeolitic material [20]. Thus, Musyoka et al. [21] prepared a single hydroxysodalite zeolite from South African coal fly ash and waste industrial brine. Zeolite P1 from fly ash under solvent-free conditions has been synthesized by Liu et al. [22]. They used the zeolitic materials for ammonium removal from water [22]. The study reported by Kunecki et al. presents an evaluation of the possibility of using Class $C$ fly ash for the synthesis of faujasite (Type X) and tschernichite (Type A) type zeolite materials [23]. A CHA Zeolite has been prepared by the use of low cost coal fly ash by Jin and coworkers [24] and Na-P zeolite was obtained by thermo-sonochemical treatment of fly ash [25].

Fly ash and zeolites have important applications in environment remediation. Thus, fly ash has been involved as adsorbent for cleaning of flue gas, removal of toxic heavy metals from wastewater, removal of other inorganic compounds such as: phosphate, fluoride, boron from wastewater, and remediation of organic compounds from wastewater [26]. Simultaneously with the development of synthesis methods, intensive research has been performed on the feasible application of the zeolites prepared from fly ash. Heavy metals such as $\mathrm{Cd}(\mathrm{II}), \mathrm{Cu}(\mathrm{II}), \mathrm{Pb}(\mathrm{II}), \mathrm{Ni}(\mathrm{II}), \mathrm{Zn}$ (II) were removed from wastewater by zeolites from fly ash [26]. One other important application of zeolites synthesized from fly ash is represented by immobilization of phosphate from wastewater [26]. In this process (phosphate precipitation) is essential presence of exchangeable Ca(II) on zeolite's surface [26]. The potential of fly ash based zeolites for adsorption of organic compounds such as phenol and o-chlorophenol from wastewater, thiophene and benzothiophene from $n$-hexane solution, methylene blue - a cationic dye and alizarin sulphonate - an anionic dye was investigated [26].

The aims of this research paper were: transforming the thermal power plant ash into zeolite materials; characterization of zeolite materials; using of zeolite materials to remove $\mathrm{Cd}(\mathrm{II})$ ions from aqueous solutions; determination of optimum conditions of the $\mathrm{Cd}(\mathrm{II})$ removal process; performing of the isothermal, kinetic and thermodynamic study of the $\mathrm{Cd}(\mathrm{II})$ sorption process.

\section{Materials and methods}

The thermal power plant ash sample was first washed and characterized before being transformed into zeolite materials by activation with $\mathrm{NaOH} 3 \mathrm{M}$ prepared from $\mathrm{NaOH}$ pellets (LabKemi origin). One stock solution (1000 mg Cd(II)/L) has been prepared from cadmium chloride, $\mathrm{CdCl}_{2} \cdot 2 \mathrm{H}_{2} \mathrm{O}$, (purchased 
from Merck, Germany). Dilutions of the $1000 \mathrm{mg} \mathrm{Cd(II)/L} \mathrm{stock} \mathrm{solution} \mathrm{at} \mathrm{desired} \mathrm{concentrations} \mathrm{were}$ prepared in $2 \% \mathrm{HCl}$ suprapure solution. The solution's $\mathrm{pH}$ was modified by adding drops of $\mathrm{HCl} 32 \%$ suprapure, $\mathrm{HCl} 1 \mathrm{~N}$ or $\mathrm{NH}_{4} \mathrm{OH} 0.1 \mathrm{~N}$ analytical grade solutions.

The alkaline activation of thermal power plant was carried out on the Heidolph MR Hei-Standard Stirrer at a rotational speed of $500 \mathrm{rpm}$ (rotations per min). The activated samples were calcinated on Caloris L1206 calcination furnance at different temperatures.

The zeolite materials prepared were characterized using modern analytical techniques such as X-ray diffraction, FT-IR analysis, specific surface determination, X-ray fluorescence spectroscopy (XRF), scanning electronmicroscopy (SEM) and particle size composition. FTIR spectra were recorded using a Fourier transformed spectrophotometer (Jasco FTIR 4100) by the use of the KBr pellet method. The specific surfaces $\left(\mathrm{S}_{\mathrm{BET}}\right)$ of the thermal power plant ash and zeolite samples were measured by adsorptiondesorption of $\mathrm{N}_{2}$ at $-196{ }^{\circ} \mathrm{C}$ on an automatic adsorption system (Micromeritics ASAP 2020) using the Brunauer Emmett Teller method based on the partial pressure adsorption data $\left(\mathrm{P} / \mathrm{P}_{\mathrm{o}}\right)$ in the range 0.05 0.3. A Thermo Fisher Scientific X-ray fluorescence spectrometer (XRF) was used to determine the ash and zeolite materials chemical composition. The acquisition of zeolite materials micrographs was accomplished using a high-resolution electronic scanning microscope, Inspect F50 at 30KeV at various magnifications. The grain size composition of the ash and zeolite materials was determined using a RETSCH sieve system

Studies on the Cd(II) ions retention were conducted with a GFL 3015 orbital shaker at a speed of $150 \mathrm{rpm}$. The $p \mathrm{H}$ of $\mathrm{Cd}(\mathrm{II})$ aqueous solutions was determined using an Agilent 3200P laboratory $p \mathrm{H}$ meter, and the $\mathrm{Cd}(\mathrm{II})$ ion content was determined by atomic absorption spectrometry using a ContrAA® 300 absorption spectrometer (Analytik Jena AG, Germany).

The retention capacity and the quantity of Cd(II) ions removed by zeolite materials at different times have been calculated using the equation:

$$
Q_{t}=\frac{\left(C_{0}-C_{t}\right) \cdot V}{m}
$$

where: $\mathrm{Q}_{\mathrm{t}}$ - the adsorption/removal capacity expressed by the amount of $\mathrm{Cd}(\mathrm{II})$ retained on the adsorbent mass unit $(\mathrm{mg} / \mathrm{g})$;

$\mathrm{C}_{0}$ - the initial concentration of $\mathrm{Cd}(\mathrm{II})$ ions in solution $(\mathrm{mg} / \mathrm{L})$;

$\mathrm{C}_{\mathrm{t}}$ - the concentration of $\mathrm{Cd}(\mathrm{II})$ ions at time $\mathrm{t}$ (or at different $p \mathrm{H}$ values) $(\mathrm{mg} / \mathrm{L})$;

$\mathrm{V}$ - the volume of solution (L);

$\mathrm{m}$ - the mass of adsorbent (samples of zeolite materials) (g).

All experiments were performed in duplicate with an experimental error within $5 \%$ range.

\section{Results and discussions}

The thermal power was firstly washed with ultrapure water to remove the soluble materials. For this step, $300 \mathrm{~g}$ of ash were weighed, contacted with $1200 \mathrm{~mL}$ of ultrapure water and stirred at room temperature on a Heidolph MR Hei-Standard magnetic stirrer at a rotational speed of $500 \mathrm{rpm}$ (rotations per minute). The washing was done for $48 \mathrm{~h}$. After washing the thermal power plant ash was filtered and dried in the oven at $105^{\circ} \mathrm{C}$.

\section{The preparation of the zeolite materials}

To prepare zeolite materials samples, the washed and dried ash was contacted with $3 \mathrm{M} \mathrm{NaOH}$ solution and then calcinated at different temperatures. Thus, over $30 \mathrm{~g}$ of washed and dried ash was added $300 \mathrm{~mL} 3 \mathrm{M} \mathrm{NaOH}$ and stirred at room temperature for $2 \mathrm{~h}$, then at $100^{\circ} \mathrm{C}$ for $4 \mathrm{~h}$. $\mathrm{NaOH}(3 \mathrm{M})$ solution was selected as activation solution, since it presents higher conversion efficiency than $\mathrm{KOH}$, under the same temperature. After cooling, the sample is filtered and calcinated at different temperatures in the oven for $8 \mathrm{~h}$. The calcination temperatures were 150,130, 110 and $90^{\circ} \mathrm{C}$. After calcination, the zeolite samples prepared were subjected to analyzes in order to establish the physico-chemical and 
morphological characteristics. The process of preparing the zeolite materials is shown in the figure below.

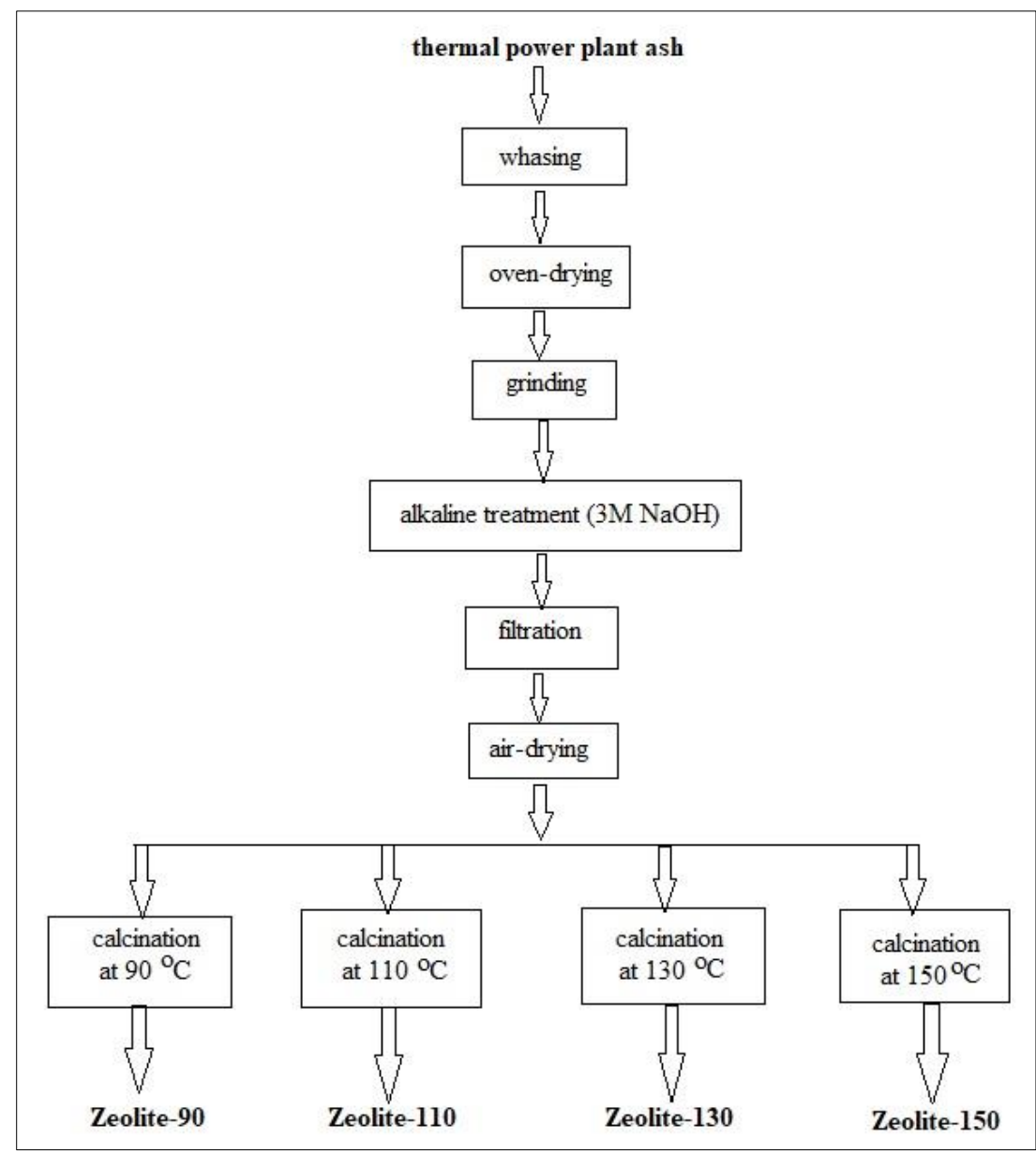

Figure 1. Scheme for preparing zeolite materials

\section{The characterization of thermal power plant as hand zeolite materials prepared}

The washed thermal power plant ash was characterized by determination of hygroscopic humidity, chemical composition and particle size composition. The thermal power plant ash has a $1.88 \%$ hygroscopic humidity determined using the drying method in the oven. The values of the hygroscopic humidity of zeolite material samples are presented in Table 1.

Table 1. Water content of zeolite samples

\begin{tabular}{|c|c|}
\hline Zeolite & Water content (\%) \\
\hline Zeolite-90 & 5.40 \\
\hline Zeolite-110 & 3.78 \\
\hline Zeolite-130 & 3.07 \\
\hline Zeolite-150 & 2.14 \\
\hline
\end{tabular}

It can be observed that Zeolite-90 sample has a higher water content compared to thermal power plant ash, and a decrease of the water content was shown with the increase of the calcination temperature.

The chemical composition of the thermal power plant ash is qualitatively similar to that of the natural materials in the composition of the earth, such as soils and shales. Oxide-like compounds of $\mathrm{Si}, \mathrm{Al}, \mathrm{Fe}$ and $\mathrm{Ca}$ account for about $90 \%$ of the composition of the thermal power plant ash. Other elements such as $\mathrm{Mg}, \mathrm{K}, \mathrm{Na}, \mathrm{Ti}, \mathrm{S}$ represent minor constituents and contribute in a very small percentage to the ash composition. In general, the power plant ash also contains other elements in the concentration of the order ppm, which represent about $1 \%$ of the ash composition. Ash is usually associated with various useful constituents such as $\mathrm{Ca}, \mathrm{Mg}, \mathrm{Mn}, \mathrm{Fe}, \mathrm{Cu}, \mathrm{Zn}, \mathrm{B}, \mathrm{S}$ and $\mathrm{P}$, but also toxic constituents such as $\mathrm{Cr}$, 
$\mathrm{Pb}, \mathrm{Hg}, \mathrm{Ni}, \mathrm{V}, \mathrm{As}$ and $\mathrm{Ba}$. The concentration of the trace elements in the ash is highly variable and depends on the coal (lignite) that has been used as raw material and on the combustion conditions and the efficiency of the emission control systems.

A Thermo Fisher Scientific X-ray fluorescence spectrometer (XRF) was used to determine the raw, washed ash chemical composition and zeolite materials prepared. The data obtained are presented in the Table 2.

Table 2. Chemical composition of of the thermal power plant ash, washed ash sample and the zeolite materials prepared

\begin{tabular}{|c|c|c|c|c|c|c|c|c|c|c|c|}
\hline \multicolumn{2}{|c|}{$\begin{array}{c}\text { Raw thermal } \\
\text { power plant ash }\end{array}$} & \multicolumn{2}{|c|}{$\begin{array}{l}\text { Washed thermal } \\
\text { power plant ash }\end{array}$} & \multicolumn{2}{|c|}{ Zeolite-90 } & \multicolumn{2}{|c|}{ Zeolite-110 } & \multicolumn{2}{|c|}{ Zeolite-130 } & \multicolumn{2}{|c|}{ Zeolite-150 } \\
\hline Comp. & $\begin{array}{l}\text { Conc. } \\
(\%)\end{array}$ & Comp. & $\begin{array}{c}\text { Conc. } \\
(\%)\end{array}$ & Comp. & $\begin{array}{c}\text { Conc. } \\
(\%)\end{array}$ & Comp. & $\begin{array}{c}\text { Conc. } \\
(\%)\end{array}$ & Comp. & $\begin{array}{c}\text { Conc. } \\
(\%)\end{array}$ & Comp. & $\begin{array}{c}\text { Conc. } \\
(\%)\end{array}$ \\
\hline $\mathrm{SiO}_{2}$ & 46.91 & $\mathrm{SiO}_{2}$ & 43.15 & $\mathrm{SiO}_{2}$ & 39.26 & $\mathrm{SiO}_{2}$ & 40.60 & $\mathrm{SiO}_{2}$ & 37.50 & $\mathrm{SiO}_{2}$ & 36.34 \\
\hline $\mathrm{Al}_{2} \mathrm{O}_{3}$ & 28.34 & $\mathrm{Al}_{2} \mathrm{O}_{3}$ & 27.14 & $\mathrm{Al}_{2} \mathrm{O}_{3}$ & 28.54 & $\mathrm{Al}_{2} \mathrm{O}_{3}$ & 28.55 & $\mathrm{Al}_{2} \mathrm{O}_{3}$ & 27.30 & $\mathrm{Al}_{2} \mathrm{O}_{3}$ & 25.93 \\
\hline $\mathrm{CaO}$ & 9.99 & $\mathrm{CaO}$ & 8.55 & $\mathrm{CaO}$ & 9.97 & $\mathrm{CaO}$ & 9.21 & $\mathrm{CaO}$ & 8.54 & $\mathrm{CaO}$ & 8.33 \\
\hline $\mathrm{Fe}_{2} \mathrm{O}_{3}$ & 7.51 & $\mathrm{Fe}_{2} \mathrm{O}_{3}$ & 6.23 & $\mathrm{Fe}_{2} \mathrm{O}_{3}$ & 7.53 & $\mathrm{Fe}_{2} \mathrm{O}_{3}$ & 6.88 & $\mathrm{Fe}_{2} \mathrm{O}_{3}$ & 6.26 & $\mathrm{Fe}_{2} \mathrm{O}_{3}$ & 6.33 \\
\hline $\mathrm{MgO}$ & 2.45 & $\mathrm{MgO}$ & 2.20 & $\mathrm{MgO}$ & 2.45 & $\mathrm{MgO}$ & 2.25 & $\mathrm{MgO}$ & 2.12 & $\mathrm{MgO}$ & 1.56 \\
\hline $\mathrm{SO}_{3}$ & 0.94 & $\mathrm{SO}_{3}$ & 0.75 & $\mathrm{SO}_{3}$ & 0.12 & $\mathrm{SO}_{3}$ & 0.13 & $\mathrm{SO}_{3}$ & 0.12 & $\mathrm{SO}_{3}$ & 0.61 \\
\hline $\mathrm{K}_{2} \mathrm{O}$ & 1.68 & $\mathrm{~K}_{2} \mathrm{O}$ & 1.32 & $\mathrm{~K}_{2} \mathrm{O}$ & 0.79 & $\mathrm{~K}_{2} \mathrm{O}$ & 0.70 & $\mathrm{~K}_{2} \mathrm{O}$ & 1.65 & $\mathrm{~K}_{2} \mathrm{O}$ & 0.40 \\
\hline $\mathrm{TiO}_{2}$ & 0.97 & $\mathrm{TiO}_{2}$ & 0.86 & $\mathrm{TiO}_{2}$ & 1.03 & $\mathrm{TiO}_{2}$ & 0.97 & $\mathrm{TiO}_{2}$ & 0.86 & $\mathrm{TiO}_{2}$ & 0.84 \\
\hline $\mathrm{Na}_{2} \mathrm{O}$ & 0.57 & $\mathrm{Na}_{2} \mathrm{O}$ & 4.30 & $\mathrm{Na}_{2} \mathrm{O}$ & 9.84 & $\mathrm{Na}_{2} \mathrm{O}$ & 10.32 & $\mathrm{Na}_{2} \mathrm{O}$ & 11.51 & $\mathrm{Na}_{2} \mathrm{O}$ & 19.35 \\
\hline $\mathrm{P}_{2} \mathrm{O}_{5}$ & 0.27 & $\mathrm{P}_{2} \mathrm{O}_{5}$ & 0.20 & $\mathrm{P}_{2} \mathrm{O}_{5}$ & 0.14 & $\mathrm{P}_{2} \mathrm{O}_{5}$ & 0.10 & $\mathrm{P}_{2} \mathrm{O}_{5}$ & 0.08 & $\mathrm{P}_{2} \mathrm{O}_{5}$ & 0.07 \\
\hline $\mathrm{BaO}$ & 0.1 & $\mathrm{BaO}$ & 0.05 & $\mathrm{BaO}$ & 0.05 & $\mathrm{BaO}$ & 0.05 & $\mathrm{BaO}$ & 0.02 & $\mathrm{BaO}$ & 0.04 \\
\hline $\mathrm{MnO}$ & 0.04 & $\mathrm{MnO}$ & 0.04 & $\mathrm{MnO}$ & 0.05 & $\mathrm{MnO}$ & 0.04 & $\mathrm{MnO}$ & 0.04 & $\mathrm{MnO}$ & 0.04 \\
\hline $\mathrm{V}_{2} \mathrm{O}_{5}$ & 0.04 & $\mathrm{~V}_{2} \mathrm{O}_{5}$ & 0.04 & $\mathrm{~V}_{2} \mathrm{O}_{5}$ & 0.03 & $\mathrm{~V}_{2} \mathrm{O}_{5}$ & 0.02 & $\mathrm{~V}_{2} \mathrm{O}_{5}$ & 0.02 & $\mathrm{~V}_{2} \mathrm{O}_{5}$ & 0.02 \\
\hline $\mathrm{SrO}$ & 0.03 & $\mathrm{SrO}$ & 0.03 & $\mathrm{SrO}$ & 0.03 & $\mathrm{SrO}$ & 0.03 & $\mathrm{SrO}$ & 0.03 & $\mathrm{SrO}$ & 0.03 \\
\hline $\mathrm{ZnO}$ & 0.01 & $\mathrm{ZnO}$ & 0.02 & $\mathrm{ZnO}$ & 0.01 & $\mathrm{ZnO}$ & 0.01 & $\mathrm{ZnO}$ & 0.02 & $\mathrm{ZnO}$ & 0.01 \\
\hline $\mathrm{Cr}_{2} \mathrm{O}_{3}$ & 0.02 & $\mathrm{Cr}_{2} \mathrm{O}_{3}$ & 0.02 & $\mathrm{Cr}_{2} \mathrm{O}_{3}$ & 0.02 & $\mathrm{Cr}_{2} \mathrm{O}_{3}$ & 0.02 & $\mathrm{Cr}_{2} \mathrm{O}_{3}$ & 0.02 & $\mathrm{Cr}_{2} \mathrm{O}_{3}$ & 0.02 \\
\hline $\mathrm{ZrO}_{2}$ & 0.02 & $\mathrm{ZrO}_{2}$ & 0.01 & $\mathrm{ZrO}_{2}$ & 0.02 & $\mathrm{ZrO}_{2}$ & 0.02 & $\mathrm{ZrO}_{2}$ & 0.01 & $\mathrm{ZrO}_{2}$ & 0.01 \\
\hline $\mathrm{CuO}$ & 0.01 & $\mathrm{CuO}$ & 0.01 & $\mathrm{CuO}$ & 0.01 & $\mathrm{CuO}$ & 0.01 & $\mathrm{CuO}$ & 0.01 & $\mathrm{CuO}$ & 0.01 \\
\hline $\mathrm{Rb}_{2} \mathrm{O}$ & 0.01 & $\mathrm{Rb}_{2} \mathrm{O}$ & 0.01 & $\mathrm{Rb}_{2} \mathrm{O}$ & 0.01 & $\mathrm{Rb}_{2} \mathrm{O}$ & 0.01 & $\mathrm{Rb}_{2} \mathrm{O}$ & 0.01 & $\mathrm{Rb}_{2} \mathrm{O}$ & 0.01 \\
\hline $\mathrm{NiO}$ & 0.01 & $\mathrm{NiO}$ & 0.01 & $\mathrm{NiO}$ & 0.01 & $\mathrm{NiO}$ & 0.01 & $\mathrm{NiO}$ & 0.01 & $\mathrm{NiO}$ & 0.01 \\
\hline
\end{tabular}

As shown in Table 2, the thermal power plant ash is a heterogeneous material having as main constituents $\mathrm{SiO}_{2}$ (43.15\%), $\mathrm{Al}_{2} \mathrm{O}_{3}$ (27.14\%), $\mathrm{CaO}$ (8.55\%) $\mathrm{Fe}_{2} \mathrm{O}_{3}$ (6.23\%), and $\mathrm{MgO}$ (2.20\%). This composition of ash can lead to the conclusion that in this case the coal used in the power plant was of the pit coal type. There is also a change in the concentration of the components of the ash sample after washing.

By analyzing data regarding the composition of zeolite materials it can be seen that the alkaline hydrothermal treatment has as result the decrease of the $\mathrm{SiO}_{2}$ content and an increase of $\mathrm{Na}_{2} \mathrm{O}$ content. This can be due to the aluminosilicate glass dissolution. The ration between $\mathrm{Si} / \mathrm{Al}$ in zeolite prepared varies between 1.21 and 1.26. According to the literature data these values for $\mathrm{Si} / \mathrm{Al}$ are specific for $\mathrm{NaP1}$ type zeolite [27]. It was also observed that the increase of temperature has as effect the decrease of $\mathrm{SiO}_{2}$ and $\mathrm{Al}_{2} \mathrm{O}_{3}$ content and the increase of $\mathrm{Na}_{2} \mathrm{O}$ content. Thus, the $\mathrm{OH}^{-}$in alkali medium notably provides the dissolution step of $\mathrm{Si}^{4+}$ and $\mathrm{Al}^{3+}$ in thermal power plant fly ash, while $\mathrm{Na}^{+}$in alkali solution influences the crystallization step of zeolite $\mathrm{NaP} 1$ [28].

SEM images of zeolite-90, zeolite-130 and zeolite-150 at different magnifications are shown in figures below. 


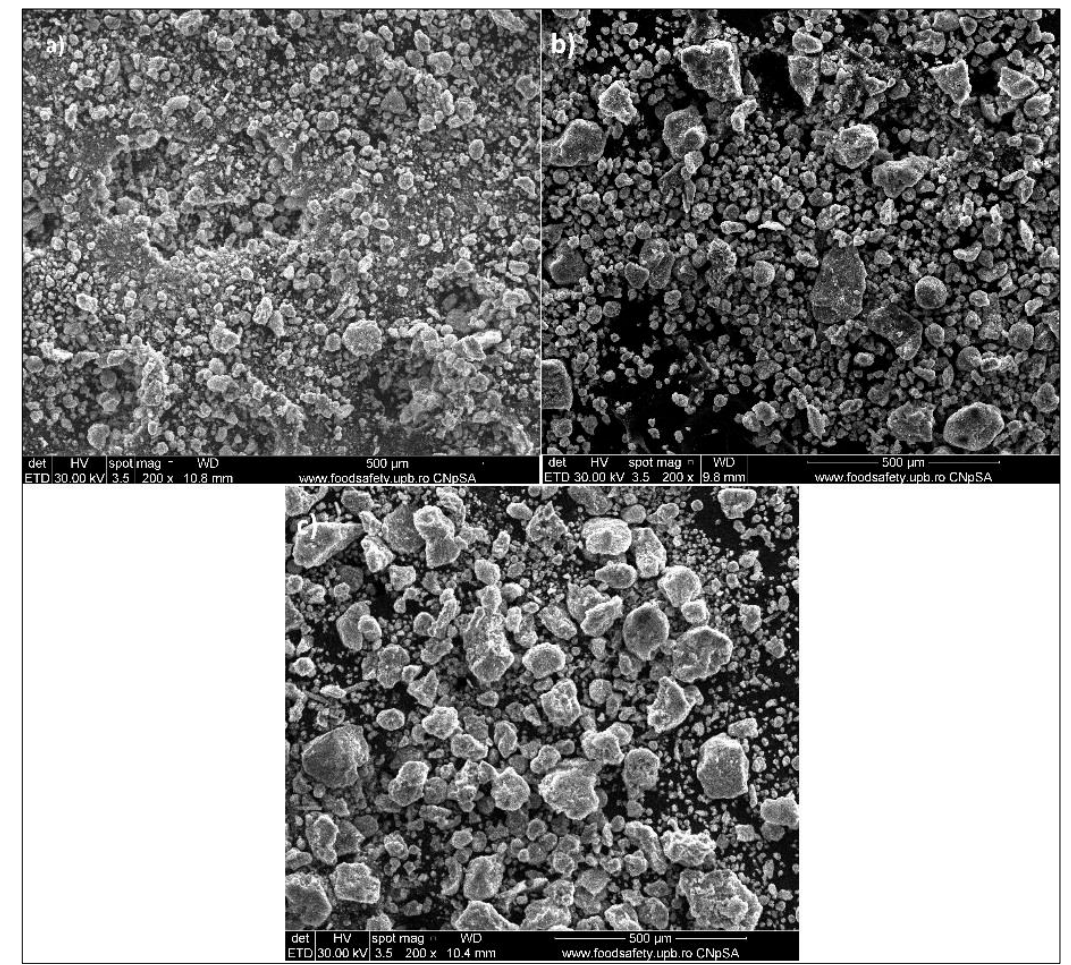

Figure 2. SEM images of zeolite-90 (a), zeolite-130 (b) and zeolite-150 (c) at 200x magnification

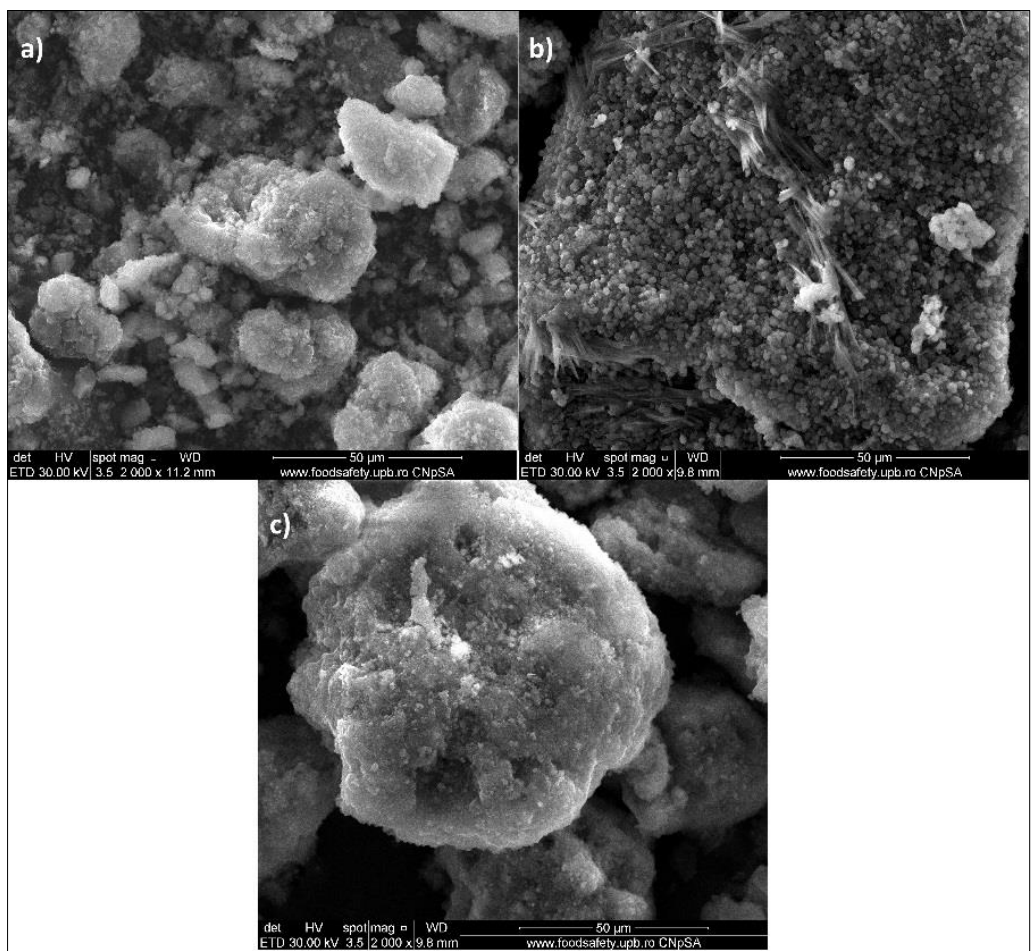

Figure 3. SEM images of zeolite-90 (a), zeolite-130 (b) and zeolite-150 (c) at 2000x magnification

In Figures 2 and 3, it is observed that zeolite particles are grains of irregular shapes. In case of treatment at $150^{\circ} \mathrm{C}$, particles with high dimensions dominate. Spherical forms occurred singularly or in aggregates, reaching diameters of between 1 and $50 \mu \mathrm{m}$. 
To determine the particle size composition, $10 \mathrm{~g}$ of ash/zeolite material was sieved using a RETSCH sieve system and the data obtained are presented in Table 3.

Table 3. The granulometric composition of the washed thermal power plant and zeolite materials

\begin{tabular}{|c|c|c|c|c|c|}
\hline \multirow{2}{*}{ Particle size fraction } & $\begin{array}{c}\text { Washed thermal } \\
\text { power plant ash }\end{array}$ & Zeolite-90 & Zeolite-110 & Zeolite-130 & Zeolite-150 \\
\cline { 2 - 6 } & Mass fraction $(\boldsymbol{\%})$ & $\begin{array}{c}\text { Mass } \\
\text { fraction }(\%)\end{array}$ & $\begin{array}{c}\text { Mass fraction } \\
(\%)\end{array}$ & $\begin{array}{c}\text { Mass fraction } \\
(\%)\end{array}$ & $\begin{array}{c}\text { Mass } \\
\text { fraction }(\%)\end{array}$ \\
\hline$>2 \mathrm{~mm}$ & 0 & 0.15 & 0.21 & 0.34 & 0 \\
\hline $2 \mathrm{~mm}-1 \mathrm{~mm}$ & 0.11 & 0.11 & 0.31 & 0.32 & 0.14 \\
\hline $1 \mathrm{~mm}-500 \mu \mathrm{m}$ & 1.47 & 0.67 & 0.45 & 0.23 & 0.95 \\
\hline $500-200 \mu \mathrm{m}$ & 4.1 & 0.35 & 0.24 & 0.08 & 0.73 \\
\hline$<200 \mu \mathrm{m}$ & 2.35 & 15.98 & 16.78 & 15.82 & 19.83 \\
\hline$<100 \mu \mathrm{m}$ & 91.97 & 82.74 & 82.01 & 83.51 & 78.35 \\
\hline
\end{tabular}

The ash fraction $<200 \mu \mathrm{m}$ has been used to alkaline treatment. It can be seen from the Table 3 that all the zeolite materials prepared have as high content the sieve fraction $<200 \mu \mathrm{m}$. Consequently, this particle size fraction was used in the adsorption experiments.

The $p \mathrm{H}$ of the washed thermal power plant ash was determined using an Agilent 3200P laboratory $\mathrm{pH}$ meter in slurry of $0.2 \mathrm{~g}$ ash and $25 \mathrm{~mL}$ of distilled water after a $24 \mathrm{~h}$ contact time between the two phases. The value obtained is 7.81 .

The raw thermal power plant ash and the washed thermal power plant ash were characterized by 5.43 $\mathrm{m}^{2} / \mathrm{g}$ and $4.81 \mathrm{~m}^{2} / \mathrm{g}$ values for specific surfaces $\left(\mathrm{S}_{\mathrm{BET}}\right)$. It can be observed a decrease of the $\mathrm{S}_{\mathrm{BET}}$ value after ash washing. The values of specific surfaces $\left(\mathrm{S}_{\mathrm{BET}}\right)$ for zeolite materials are presented compared to the value of $\mathrm{S}_{\mathrm{BET}}$ determined for washed ash in the Table 4.

Table 4. The specific surface values for zeolite materials and washed thermal power plant ash

\begin{tabular}{|c|c|}
\hline Tested material & Specific surface $\mathbf{S}_{\text {BET }}\left(\mathbf{m}^{2} / \mathbf{g}\right)$ \\
\hline Washed thermal power plant ash & 4.81 \\
\hline Zeolite-90 & 11.23 \\
\hline Zeolite-110 & 15.54 \\
\hline Zeolite-130 & 23.62 \\
\hline Zeolite-150 & 40.77 \\
\hline
\end{tabular}

Data from Table 4 have revealed an increase of the value of specific surface $\left(\mathrm{S}_{\mathrm{BET}}\right)$ by transforming of the thermal power plant ash into zeolite materials. In addition, it was found that the increase of the temperature of thermal treatment has as result an increase of the specific surface. The high value of specific surface was determined for Zeolite-150. This value is higher with a factor of 8.5 compared to the value of $S_{\text {BET }}$ presented by thermal power plant ash.

FT-IR spectrometry was used to characterize the structural aspects of the thermal power plant ash and the synthesized zeolites. For this purpose, the FT-IR spectra presented in the figure below were recorded in the wavelength range $400-4000 \mathrm{~cm}^{-1}$. 


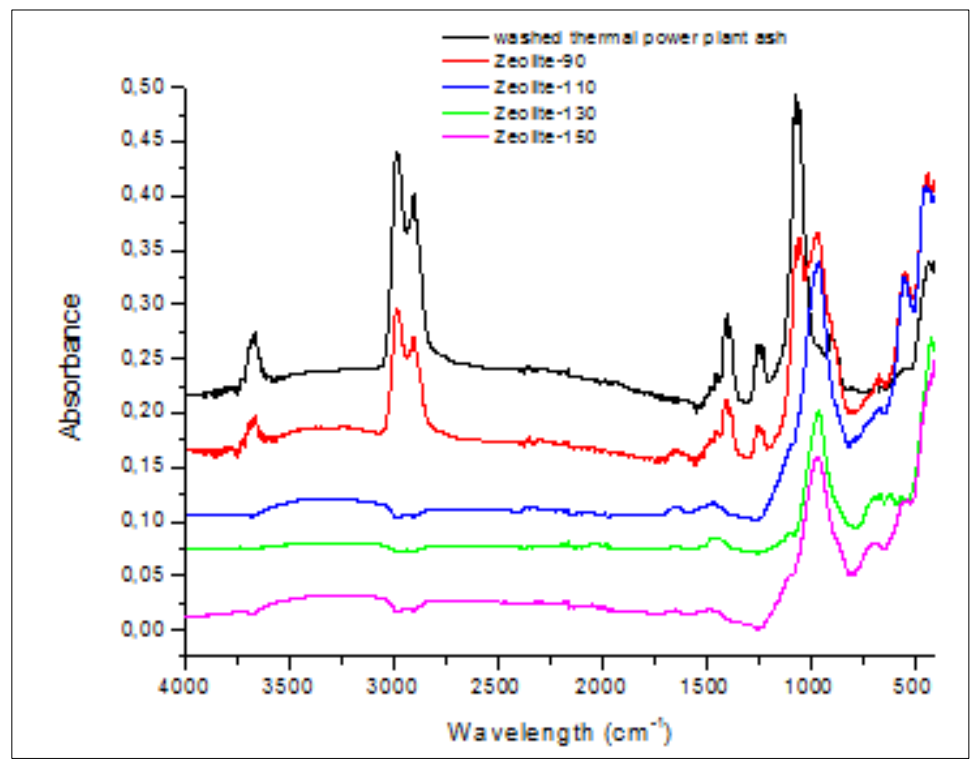

Figure 4. FT-IR spectra of washed thermal power plant ash and zeolite materials

The FTIR spectrum of the thermal power plant ash presents four important peaks that describe the characteristics of aluminosilicate minerals. These peaks occur at wavelengths 433, 673, 873, 1066, which are characteristic of the symmetrical stretching vibrations of the Si-O, Si-O-Si and Al-O-Si bonds [29].

The band occurring at $673 \mathrm{~cm}^{-1}$ is characteristic for T-O (where, T =Al, Si) symmetric stretching vibrations that correspond to quartz present in the fly ash and the band occurring at $1066 \mathrm{~cm}^{-1}$ is associated with T-O asymmetric stretching vibrations [29]. A very weak band at $773 \mathrm{~cm}^{-1}$ reveals presence of mullite in thermal power plant ash [30]. The sharp band found at $3684 \mathrm{~cm}^{-1}$ is characteristic for $-\mathrm{OH}$ groups from water molecules.

A very intense band that appears in the wavelength range $2900-2990 \mathrm{~cm}^{-1}$ indicates the presence of organic carbon in the ash structure [31].

The band that appears at wavelength $1393 \mathrm{~cm}^{-1}$ indicates the presence of carbonates, and the band at wavelength $1250 \mathrm{~cm}^{-1}$ indicates the presence of nitrates in the composition of the thermal power plant.

The transformation of the thermal power plant ash into zeolite materials is confirmed by the changes that occur in the FT-IR spectra of the zeolite materials. Antisymmetric stretch vibration bands common to zeolites generally occur in the region of $950-1250 \mathrm{~cm}^{-1}[26]$.

The very strong band, characteristic of the asymmetrical stretching vibrations of the T-O tetrahedrons from the thermal power plant ash that appears in the spectrum at wavelength $1066 \mathrm{~cm}^{-1}$ is shifted to smaller wavelengths $\left(967 \mathrm{~cm}^{-1}\right.$ in the case of zeolite prepared at $90^{\circ} \mathrm{C}, 960 \mathrm{~cm}^{-1}$ for zeolite prepared at $110^{\circ} \mathrm{C}, 959 \mathrm{~cm}^{-1}$ for zeolite prepared at $130^{\circ} \mathrm{C}, 963 \mathrm{~cm}^{-1}$ for zeolite prepared at $150^{\circ} \mathrm{C}$ ). The shifting of this band and the decrease in intensity indicates the transformation of the thermal power plant ash into zeolite materials [310]. The shifting also indicates that the vitreous component of the thermal power plant ash reacted with the alkaline activator $(\mathrm{NaOH})$ to form the zeolite materials [26].

Another important change observed in the FT-IR spectra of the prepared zeolite materials is the decrease in the intensity of the band characteristic of the organic matter and of the one characteristic of the water molecules, a decrease which is the more significant, as the calcination temperature is higher.

\section{Adsorption study}

The synthetic zeolitic materials have been used to treat aqueous solutions with $\mathrm{Cd}(\mathrm{II})$ ions content in order to determine their ability to remove the pollutants from heavy metal contaminated aqueous solutions. The optimum experimental conditions have been determined by batch tests. 


\section{Influence of $p \mathbf{H}$}

The $p \mathrm{H}$ of the solution/wastewater is one the most important operational parameters in the removal process due to the fact that it can affect the characteristics of adsorbent such as the concentration of the counter ions on the functional groups, the degree of ionization of the adsorbate, the solubility of the metal ions and the nature of the heavy metal species present in the solution [32]. It is well known that at higher $p \mathrm{H}$ values, most of the heavy metal ions precipitate as hydroxides and the adsorption of heavy metal ions will compete with precipitation. Consequently, the adsorption of $\mathrm{Cd}(\mathrm{II})$ ions onto zeolite materials prepared at $p \mathrm{H}$ value ranging from 2.5 to 7.5 was studied as shown in Figure 5.

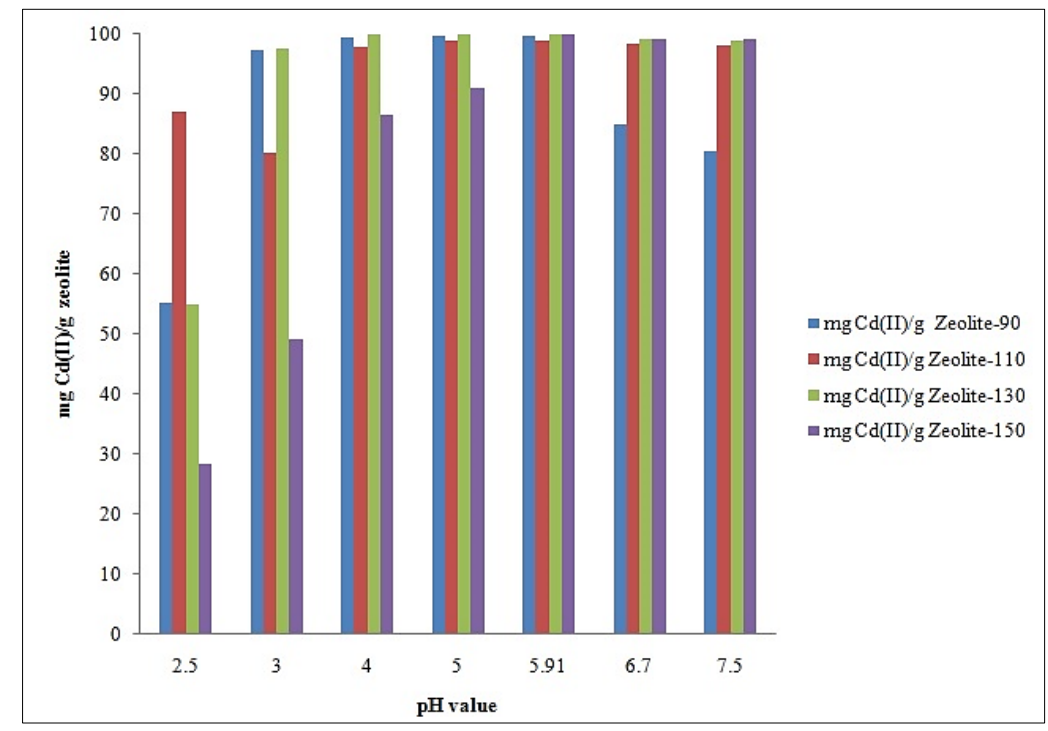

Figure 5. The effect of $\mathrm{pH}$ value on $\mathrm{Cd}(\mathrm{II})$ ions adsorption (initial $\mathrm{Cd}(\mathrm{II})$ ions concentration $=100 \mathrm{mg} / \mathrm{L}$; contact time $=360 \mathrm{~min}$; adsorbent dose $=50 \mathrm{mg} / 50 \mathrm{~mL}$; temperature $=20 \pm 2^{\circ} \mathrm{C}$ )

From Figure 5, it can be concluded that an increase in $p \mathrm{H}$ corresponds to an increase in adsorption, reaching the maximum adsorption capacity at a $p \mathrm{H}$ of about 5.91 (this $p \mathrm{H}$ value corresponds to the $p \mathrm{H}$ value of the initial $100 \mathrm{mg} / \mathrm{L} \mathrm{Cd(II)} \mathrm{solution).} \mathrm{The} \mathrm{lower} \mathrm{adsorption} \mathrm{of} \mathrm{heavy} \mathrm{metal} \mathrm{at} \mathrm{acidic} p \mathrm{H}$ can be explained by the fact that at lower $p \mathrm{H}$ values, where the concentration of $\mathrm{H}_{3} \mathrm{O}^{+}$is high, the competition by the negative sites on the zeolite surface is enhanced and the $\mathrm{Cd}(\mathrm{II})$ ions sorption is reduced accordingly [31]. Moreover, at low $p \mathrm{H}$ value the zeolite crystals will dissolve and they will be hard to be removed from treated water. A slow decrease of the adsorption capacity has been registered at $p \mathrm{H}$ value higher than 5.91. The optimum $p \mathrm{H}$ value experimentally determined is 5.91 for all zeolite materials prepared.

The results regarding the effect of the $p \mathrm{H}$ onto zeolite materials adsorption capacity are in agreement with the results previously reported by other authors [32].

\section{Effect of the contact time}

Another important operational parameter is the contact time required to reach the adsorption equilibrium. The adsorption of $\mathrm{Cd}(\mathrm{II})$ onto zeolite materials, as a function of contact time was examined at $20 \pm 2{ }^{\circ} \mathrm{C}$ (room temperature) by varying the contact time from 5 to $420 \mathrm{~min}$. The results are displayed in Figure 6. 


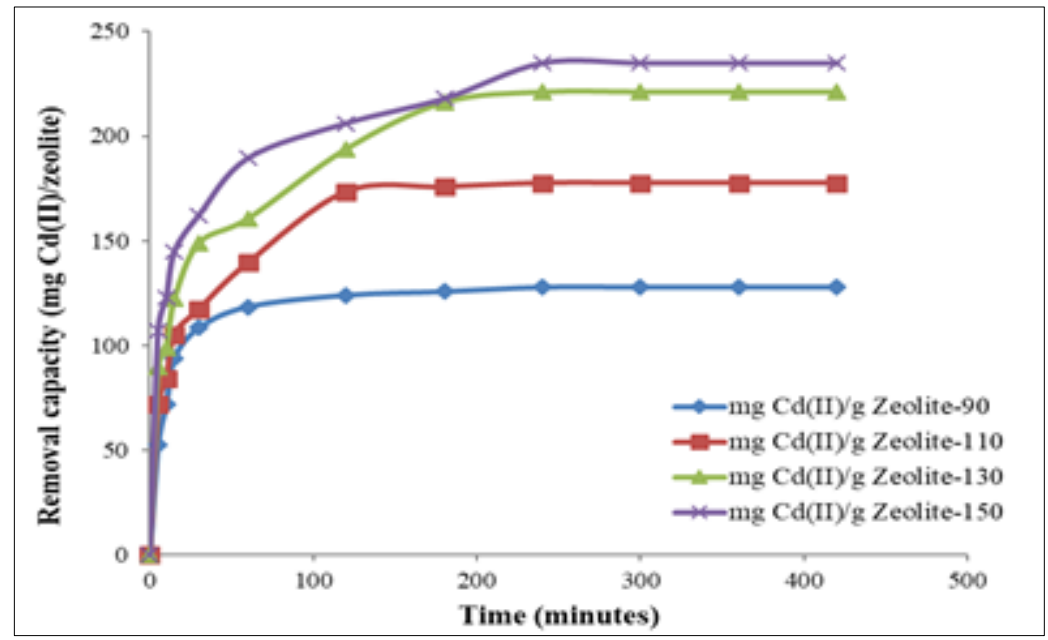

Figure 6. Effect of the contact time on Cd(II) adsorption capacity (initial $\mathrm{Cd}(\mathrm{II})$ ions concentration $=100 \mathrm{mg} / \mathrm{L}$; $p \mathrm{H}$ value $=5.91 ;$ adsorbent dose $=0.01 \mathrm{~g} / 50 \mathrm{~mL}$; temperature $=20 \pm 2{ }^{\circ} \mathrm{C}$ )

From Figure 6, it can be observed that the adsorption of the Cd(II) ions is increased from the beginning and then kept increasing gradually until the equilibrium is reached and then it remained constant. The removal rate of $\mathrm{Cd}(\mathrm{II})$ is faster at the initial stage because initially, all the zeolite sites are vacant and the $\mathrm{Cd}(\mathrm{II})$ concentration gradient is high [32]. The time to reach the equilibrium is 240 minutes for all four zeolite materials demonstrating that they have a strong ability for binding $\mathrm{Cd}(\mathrm{II})$ ions. Thus, a contact time of $240 \mathrm{~min}$ was found to be sufficient to achieve uptake equilibrium, and the contact time was fixed at $240 \mathrm{~min}$ for the following batch experiments.

The adsorption capacity of zeolite materials increases with the increase of the temperature of the thermal treatment. Thus, the lowest adsorption capacity $(127.75 \mathrm{mg} \mathrm{Cd}(\mathrm{II}) / \mathrm{g}$ adsorbent) was determined for zeolite material prepared at $90^{\circ} \mathrm{C}$ and the highest adsorption capacity ( $234.85 \mathrm{mg} \mathrm{Cd}(\mathrm{II}) / \mathrm{g}$ adsorbent) was established for zeolite material prepared at $150^{\circ} \mathrm{C}$.

\section{Effect of adsorbent dose}

The removal of $\mathrm{Cd}(\mathrm{II})$ on synthetized zeolite materials was investigated on various amounts of adsorbents from 0.01 to $0.15 \mathrm{~g}$. The results obtained are illustrated on Figure 7.

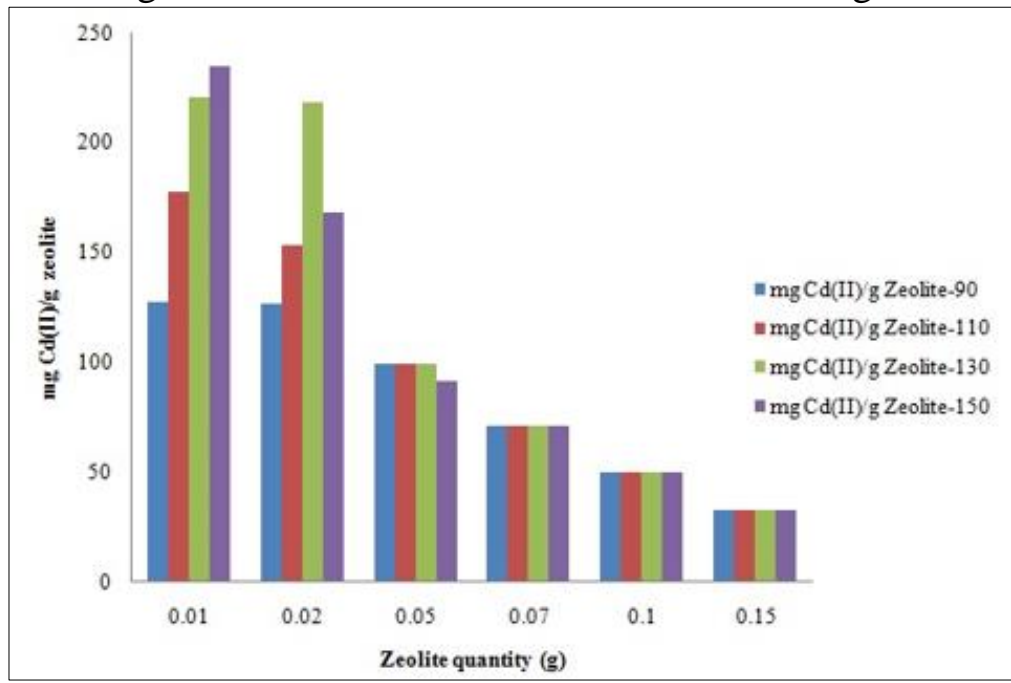

Figure 7. Effect of the adsorbent dose on Cd(II) adsorption capacity (initial Cd(II) ions concentration $=100 \mathrm{mg} / \mathrm{L}$; $p \mathrm{H}$ value $=5.91 ;$ contact time $=240 \mathrm{~min} ;$ temperature $=20 \pm 2^{\circ} \mathrm{C}$ ) 
Figure 7 shows that the maximum adsorption capacity was determined for an adsorbent dose equal to $0.01 \mathrm{~g} / 50 \mathrm{~mL}$. Increasing of the dose of sorbent did not lead to an increase in the adsorption capacity, which could be attributed to saturation of the binding sites [31].

\section{Adsorption isotherm}

The experimental data were fitted with Langmuir and Freundlich isotherms which are two of the most commonly used equilibrium models [32].

According to the Langmuir isotherm model the uptake occurs on homogeneous surface by monolayer sorption without interaction between sorbed molecules [32]. The linear form of Langmuir's isotherm model is presented as follows:

$$
\frac{\mathrm{C}_{\mathrm{e}}}{\mathrm{Q}_{\mathrm{e}}}=\frac{1}{\mathrm{Q}_{\max }} \cdot \mathrm{C}_{\mathrm{e}}+\frac{1}{\mathrm{Q}_{\max } \cdot \mathrm{K}_{\mathrm{L}}}
$$

where: $\mathrm{C}_{\mathrm{e}}$ is the liquid equilibrium concentration of $\mathrm{Cd}(\mathrm{II})$ ions in the solution $(\mathrm{mg} / \mathrm{L})$,

$\mathrm{K}_{\mathrm{L}}$ is the sorption equilibrium constant parameter of the Langmuir model related to the energy of adsorption ( $\mathrm{L} / \mathrm{mg})$,

$\mathrm{Q}_{\mathrm{e}}$ represents the amount of $\mathrm{Cd}(\mathrm{II})$ ions retained at equilibrium $(\mathrm{mg} / \mathrm{g})$,

$\mathrm{Q}_{\max }$ is the maximum adsorption capacity $(\mathrm{mg} / \mathrm{g})$ [32].

The Freundlich isotherm is an empirical mathematical equation (3) engaged to describe heterogeneous systems [32].

$$
\ln Q=\ln K_{F}+\frac{1}{n} \ln C_{e}
$$

where: $\mathrm{K}_{\mathrm{f}}$ and $1 / \mathrm{n}$ are the parameters of the Freundlich adsorption isotherm (adsorption capacity and intensity),

$\mathrm{C}_{\mathrm{e}}$ is the liquid equilibrium concentration of $\mathrm{Cd}(\mathrm{II})$ ions in the solution $(\mathrm{mg} / \mathrm{L})$.

These linear forms of the adsorption isotherms have been employed for processing of the experimental data regarding $\mathrm{Cd}(\mathrm{II})$ sorption onto zeolite materials.

The isotherm experimental data, which were collected at different initial $\mathrm{Cd}(\mathrm{II})$ ion concentrations ranging from 5 to $100 \mathrm{mg} / \mathrm{L}$, were plotted between $\mathrm{C}_{\mathrm{e}} / \mathrm{Q}_{\mathrm{e}}$ versus $\mathrm{C}_{\mathrm{e}}$ (Figure 8).

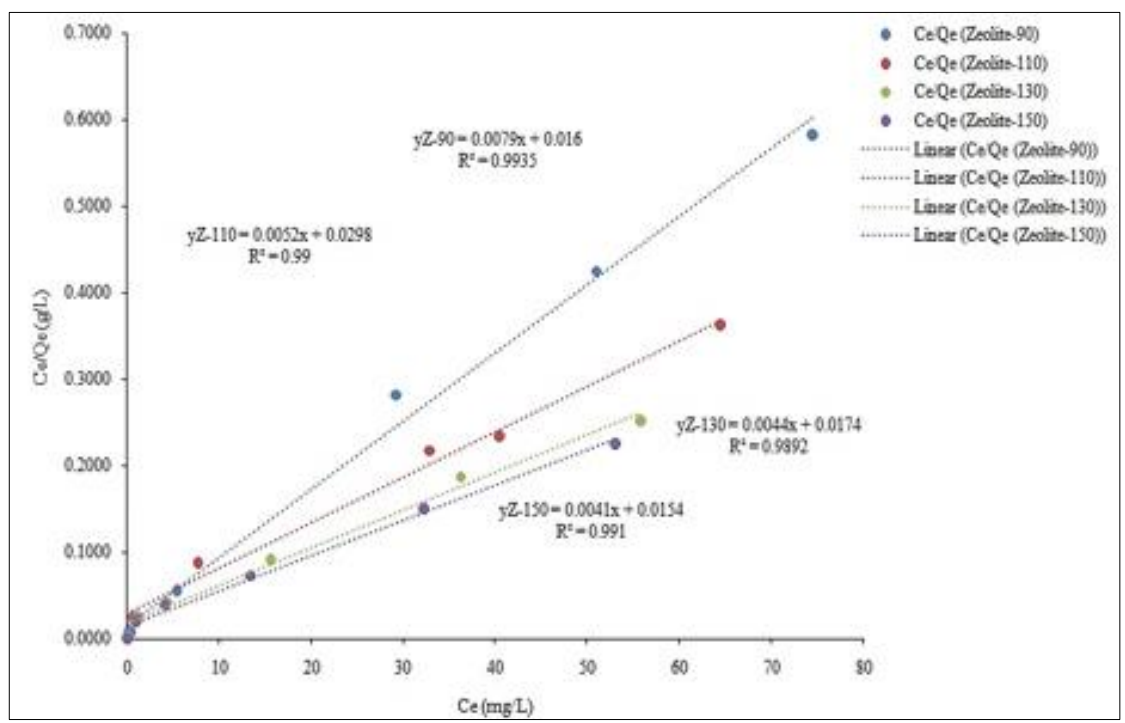

Figure 8. Langmuir isotherm adsorption model of the $\mathrm{Cd}(\mathrm{II})$ onto zeolite materials (adsorbent dose $=0.01 \mathrm{~g} / 50 \mathrm{~mL}$;

contact time $=240 \mathrm{~min} ; p \mathrm{H}$ value $=5.91 ;$ temperature $\left.=20 \pm 2{ }^{\circ} \mathrm{C}\right)$ 
Freundlich isothermal plots are presented in Figure 9.

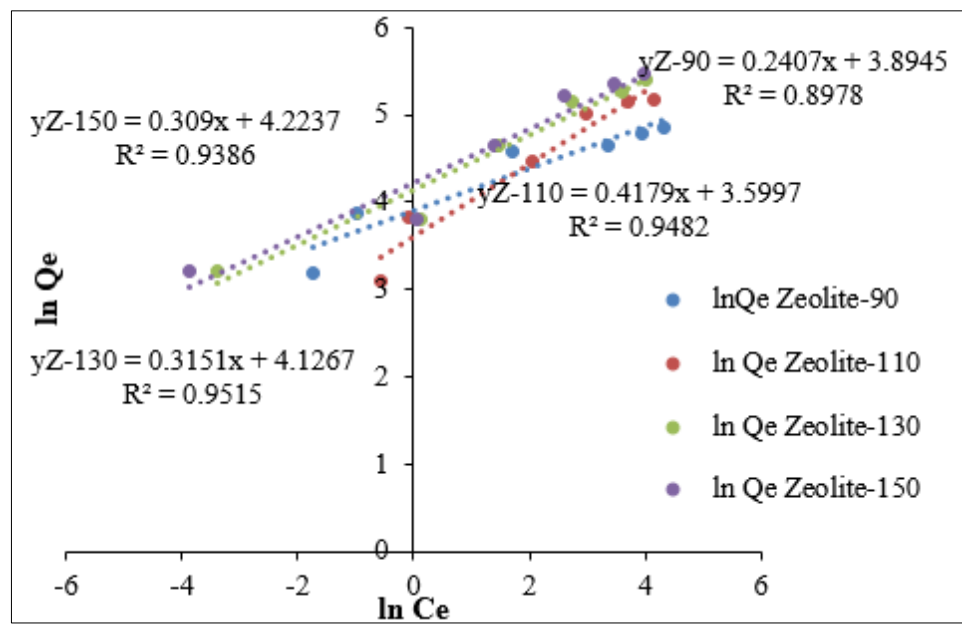

Figure 9. Freundlich isotherm adsorption model of the $\mathrm{Cd}(\mathrm{II})$

onto zeolite materials (adsorbent dose $=0.01 \mathrm{~g} / 50 \mathrm{~mL}$;

contact time $=240 \mathrm{~min} ; p \mathrm{H}$ value $=5.91 ;$ temperature $=20 \pm 2^{\circ} \mathrm{C}$ )

The Langmuir and Freundlich constants and the statistical fits of the Cd(II) sorption data to these equations are listed in Table 5.

Table 5. The Langmuir and Freundlich isotherm parameters for cd(ii) sorption onto zeolite materials

\begin{tabular}{|c|c|c|c|c|c|c|c|}
\hline \multirow{2}{*}{ Adsorbent } & \multicolumn{3}{|c|}{ Langmuir Parameters } & \multicolumn{3}{c|}{ Freundlich Parameters } \\
\cline { 2 - 8 } & $\mathrm{Q}_{\max }(\mathrm{mg} / \mathrm{g})$ & $\mathrm{K}_{\mathrm{L}}(\mathrm{L} / \mathrm{mg})$ & $\mathrm{R}^{2}$ & $\mathrm{R}_{\mathrm{L}}$ & $\mathrm{K}_{\mathrm{F}}(\mathrm{mg} / \mathrm{g})$ & $\mathrm{n}$ & $\mathrm{R}^{2}$ \\
\hline Zeolite-90 & 126.58 & 0.4938 & 0.9935 & 0.0198 & 49.13 & 4.1545 & 0.8978 \\
\hline Zeolite-110 & 192.31 & 0.1745 & 0.9900 & 0.0542 & 36.59 & 2.3929 & 0.9482 \\
\hline Zeolite-130 & 227.27 & 0.2529 & 0.9892 & 0.0380 & 61.97 & 3.1736 & 0.9515 \\
\hline Zeolite-150 & 243.90 & 0.2662 & 0.991 & 0.0362 & 68.29 & 3.2362 & 0.9386 \\
\hline
\end{tabular}

Regression values $\left(\mathrm{R}^{2}\right)$ shown in Table 6 indicated that the sorption data for $\mathrm{Cd}(\mathrm{II})$ ions removal fitted well the Langmuir isotherm. Meanwhile, the high value of correlation coefficient $\left(\mathrm{R}^{2}>0.9892\right)$ for the Langmuir isotherm predicts the monolayer coverage of $\mathrm{Cd}(\mathrm{II})$ ions on zeolite particles [33].

A dimensionless separation factor $\left(R_{L}\right)$ defined as follows represents one of the fundamental characteristics of the Langmuir equation:

$$
\mathrm{R}_{\mathrm{L}}=\frac{1}{\left(1+\mathrm{K}_{\mathrm{L}} \times \mathrm{C}_{0}\right)}
$$

where: $\mathrm{C}_{0}$ is the highest initial $\mathrm{Cd}(\mathrm{II})$ ions concentration $(\mathrm{mg} / \mathrm{L})$,

$\mathrm{K}_{\mathrm{L}}$ is the Langmuir's adsorption constant $(\mathrm{L} / \mathrm{mg})[33]$.

The $\mathrm{R}_{\mathrm{L}}$ value can be used to predict if the Langmuir model describes favorable the sorption process studied. Thus, the $R_{L}$ value implies the adsorption to be unfavorable $\left(R_{L}>1\right)$, linear $\left(R_{L}=1\right)$, favorable $\left(0<\mathrm{R}_{\mathrm{L}}<1\right)$ or irreversible $\left(\mathrm{R}_{\mathrm{L}}=0\right)$ [33]. For zeolite materials tested, the values of $\mathrm{R}_{\mathrm{L}}$ range from 0.0198 to 0.0542 for $\mathrm{Cd}$ (II) (Table 6). According to these values it can be said that the adsorption of Cd(II) ions onto zeolite materials prepared is considered favorable.

The results of the isothermal modelling of the sorption of $\mathrm{Cd}(\mathrm{II})$ ions on zeolite materials follows the Langmuir isotherm model that stated that the removal occurs on homogeneous surface by monolayer sorption without interaction between sorbed ions [33].

\section{Adsorption kinetics}

The kinetics of sorption of $\mathrm{Cd}(\mathrm{II})$ ions by zeolite materials was studied for its possible transforming from lab scale experiments to pilot remediation of metal-bearing industrial wastewater. Consequently, 
the kinetic behavior of the $\mathrm{Cd}(\mathrm{II})$ ion removal by different zeolite prepared samples has been examined, using the pseudo-first, the pseudo-second order kinetics, and intraparticle diffusion kinetic models.

The pseudo first-order kinetic model assumes that the rate of adsorption is proportional to the number of free active centers on the surface of the adsorbent/zeolite materials [34, 35]. This model is indicated by the linear Lagergren equation (5):

$$
\log \left(Q_{e}-Q_{t}\right)=\log Q_{e}-\frac{k_{1}}{2.303} \times t
$$

where: $\mathrm{k}_{1}$ is the rate constant of the pseudo first-order sorption process $\left(\mathrm{min}^{-1}\right)$ and

$\mathrm{Qe}, \mathrm{Qt}$ are the equilibrium sorption capacity and, respectively, the amount of $\mathrm{Cd}(\mathrm{II})$ ions retained on adsorbent at time $\mathrm{t}(\mathrm{mg} / \mathrm{g})$ [36].

The kinetic model of pseudo second-order sorption is expressed using Ho equation [37]:

$$
\frac{t}{Q_{t}}=\frac{1}{k_{2} \times Q_{e}^{2}}+\frac{t}{Q_{e}}
$$

where: $\mathrm{k}_{2}$ represents the rate constant of the pseudo second-order sorption process of $(\mathrm{g} / \mathrm{mg} / \mathrm{min})$;

Qe, Qt are the equilibrium sorption capacity and, respectively, the amount of $\mathrm{Cd}(\mathrm{II})$ ions retained on adsorbent at time $\mathrm{t}(\mathrm{mg} / \mathrm{g})$.

The pseudo second-order model reveals that the main mechanism involved in the process is chemisorption.

The intraparticulate diffusion kinetic model is mathematically expressed by the equation (7) submitted in 1962 by Weber and Morris [38].

$$
\mathrm{Q}_{\mathrm{t}}=\mathrm{k}_{\mathrm{i}} \mathrm{t}^{0.5}+C
$$

where $\mathrm{k}_{\mathrm{i}}$ is the intraparticulate diffusion rate constant $\left(\mathrm{mg} / \mathrm{g} \cdot \mathrm{min}^{0.5}\right)$, and $\mathrm{C}(\mathrm{mg} / \mathrm{g})$ is the intercept which gives indications about the thickness of the diffusion layer.

The constants of these models were found through a regression analysis over the acquired experimental data. The plots showing the match between the experimental data and the models are presented in the Figures 8-10 and the regression analysis results are presented in the Table 7.

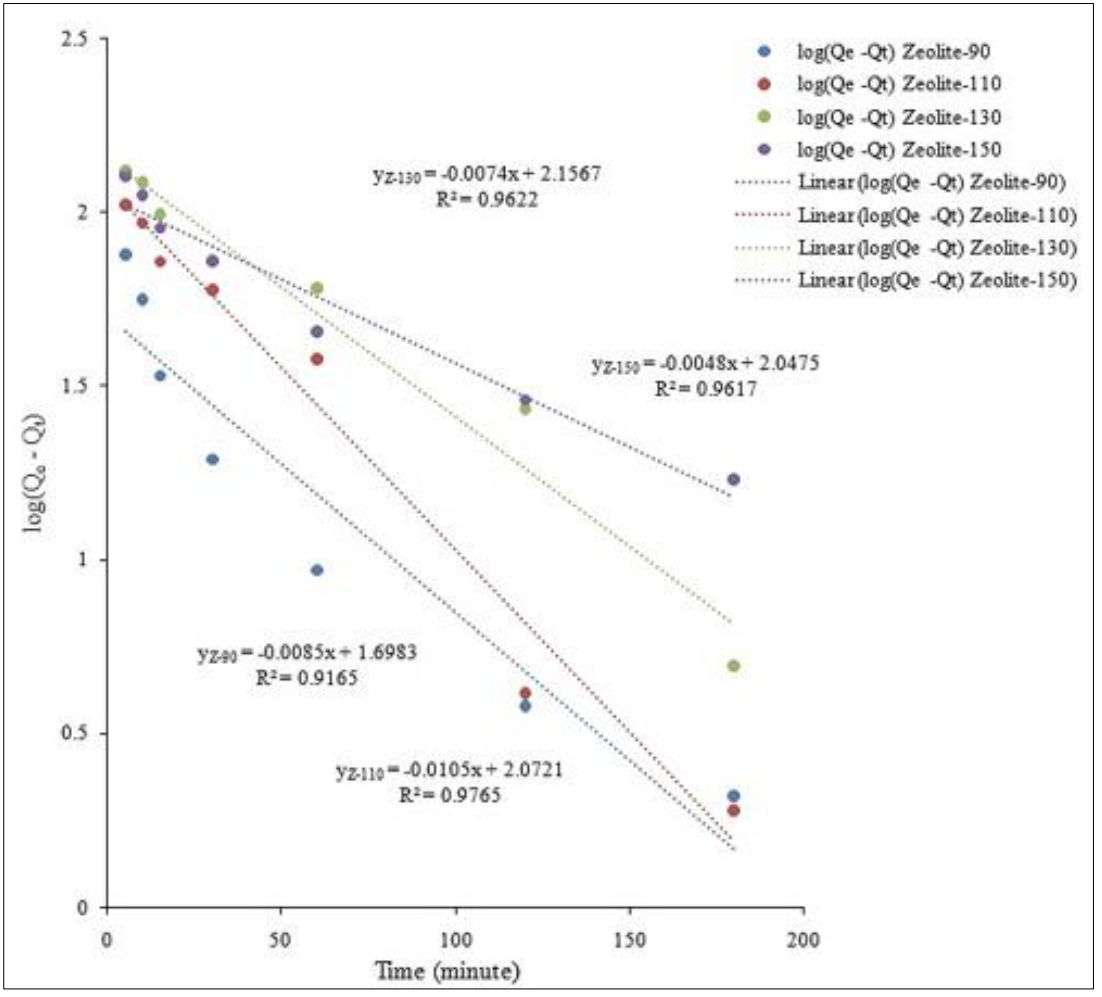

Figure 10. Plots of the pseudofirst order kinetics of $\mathrm{Cd}(\mathrm{II})$ removal by the zeolite materials (initial $\mathrm{Cd}(\mathrm{II})$ ions concentration $=100 \mathrm{mg} / \mathrm{L}$; adsorbent dose $=0.01 \mathrm{~g} / 50 \mathrm{~mL}$;

$$
p \mathrm{H} \text { value }=5.91 \text {; }
$$
temperature $=20 \pm 2^{\circ} \mathrm{C}$ ) 


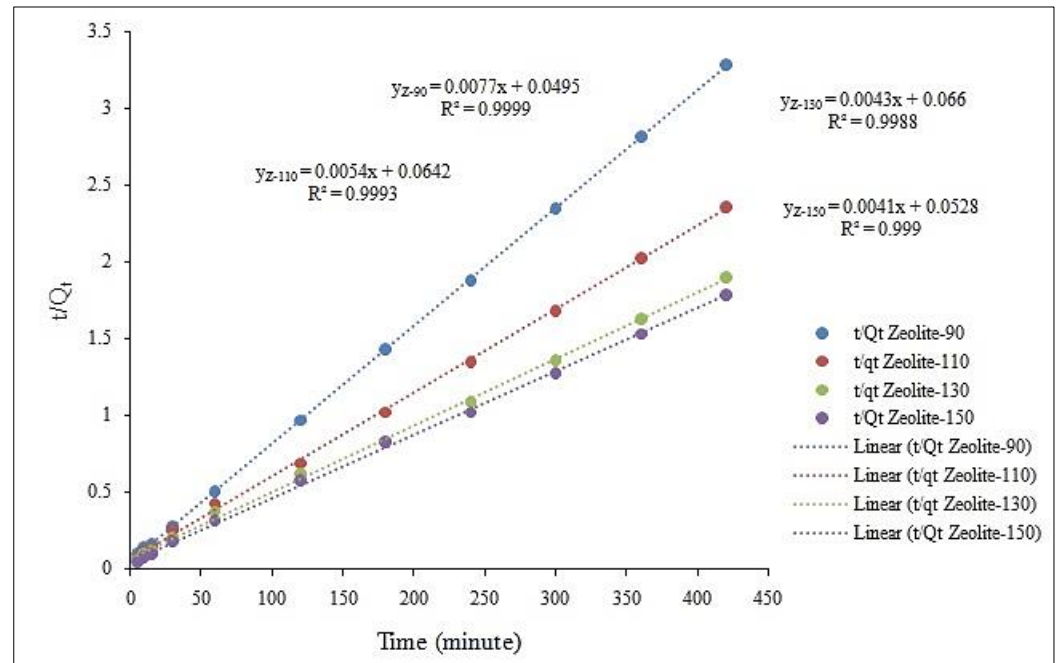

Figure 11. Plots of the pseudo-second order kinetics of $\mathrm{Cd}(\mathrm{II})$ removal by the zeolite materials (initial Cd(II) ions concentration $=100 \mathrm{mg} / \mathrm{L}$; adsorbent dose $=0.01 \mathrm{~g} / 50 \mathrm{~mL} ; p \mathrm{H}$ value $=5.91 ;$ temperature $=20 \pm 2^{\circ} \mathrm{C}$ )

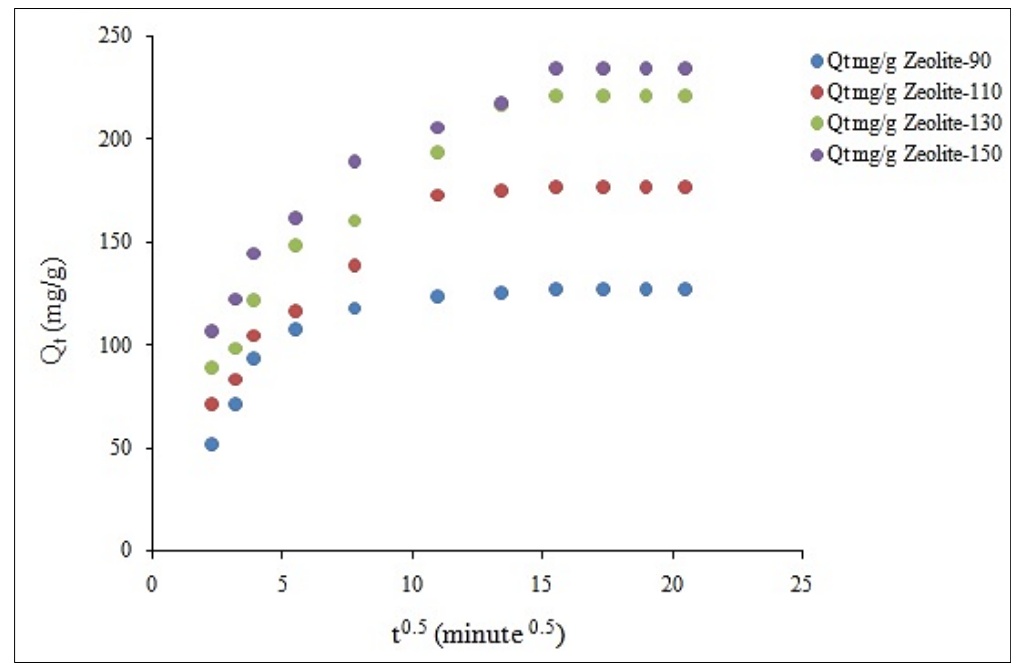

Figure 12. Plots of the intraparticle diffusion kinetics of $\mathrm{Cd}(\mathrm{II})$ removal by the zeolite materials (initial $\mathrm{Cd}(\mathrm{II})$ ions concentration $=100 \mathrm{mg} / \mathrm{L}$; adsorbent dose $=0.01 \mathrm{~g} / 50 \mathrm{~mL}$; $p \mathrm{H}$ value $=5.91 ;$ temperature $=20 \pm 2^{\circ} \mathrm{C}$ )

Figure 13 reveals that for all zeolite tested materials, it is possible to draw two lines from the graphical representation of $\mathrm{Q}_{\mathrm{t}}$ versus $\mathrm{t}^{0.5}$ which can lead to the conclusion that the studied adsorption process could take place in two steps: the external diffusion followed by the intraparticle diffusion. Due to the fact that the lines do not pass through the origin, it can be concluded that the adsorption process of the $\mathrm{Cd}(\mathrm{II})$ ions on the zeolite prepared materials can't be modeled using the kinetic diffusion intraparticle model.

Table 6. The values of the kinetic parameters for the adsorption process of cd(ii) ions on zeolite materials

\begin{tabular}{|c|c|c|c|c|}
\hline \multirow{2}{*}{ Adsorbent } & \multicolumn{2}{|c|}{ Pseudo-first-order kinetic } & \multicolumn{2}{c|}{ Pseudo-second-order kinetic } \\
\cline { 2 - 4 } & $\mathrm{k}_{1}\left(\mathrm{~min}^{-1}\right)$ & $\mathrm{R}^{2}$ & $\mathrm{k}_{2}(\mathrm{~g} / \mathrm{mg} \cdot \mathrm{min})$ & $\mathrm{R}^{2}$ \\
\hline Zeolite-90 & $1.9575 \cdot 10^{-2}$ & 0.9165 & $1.1978 \cdot 10^{-3}$ & 0.9999 \\
\hline Zeolite-110 & $2.4182 \cdot 10^{-2}$ & 0.9765 & $4.5421 \cdot 10^{-4}$ & 0.9993 \\
\hline Zeolite-130 & $1.7042 \cdot 10^{-2}$ & 0.9622 & $2.8015 \cdot 10^{-4}$ & 0.9988 \\
\hline Zeolite-150 & $1.1054 \cdot 10^{-2}$ & 0.9617 & $3.1837 \cdot 10^{-4}$ & 0.999 \\
\hline
\end{tabular}


The results presented in Table 6 show that, for Cd(II) sorption process the $\mathrm{R}^{2}$ values $\left(\mathrm{R}^{2}\right.$ ranging from 0.9165 to 0.9765 ) for pseudo-first order kinetic model were much lower than those obtained using the pseudo-second-order kinetic model ( $\mathrm{R}^{2}$ is in the range from 0.9988 to 0.9999$)$. Thus, the pseudosecond-order kinetic model explains better the $\mathrm{Cd}(\mathrm{II})$ sorption onto zeolite materials processes. Consequently, the mechanism involved in $\mathrm{Cd}(\mathrm{II})$ sorption onto zeolite materials is based on chemical reactions.

\section{Thermodynamic study}

The thermodynamic parameters such as change in Gibbs free energy $\left(\Delta \mathrm{G}^{\circ}\right)$, change in entropy $\left(\Delta \mathrm{S}^{\circ}\right)$ and change in enthalpy $\left(\Delta \mathrm{H}^{\circ}\right)$ for $\mathrm{Cd}(\mathrm{II})$ adsorption process on zeolite materials have been determined from Van't Hoff equation (8).

$$
\ln \mathrm{k}_{\mathrm{C}}=-\frac{\Delta \mathrm{H}^{\circ}}{\mathrm{RT}}+\frac{\Delta \mathrm{S}^{\circ}}{\mathrm{R}}
$$

where: $\mathrm{k}_{\mathrm{C}}$ is the equilibrium sorption constant depending on the temperature,

$\mathrm{R}$ is the universal gas constant $\left(8.314 \mathrm{~J} \cdot \mathrm{mol}^{-1} \cdot \mathrm{K}^{-1}\right)$ and

$\mathrm{T}$ (degrees Kelvin) is the absolute temperature. $\Delta \mathrm{S}^{\circ}$.

The slope and intercept of the plot of $\ln (\mathrm{Qe} / \mathrm{Ce})$ versus $1 / \mathrm{T}$ were involved in calculation of $\Delta \mathrm{H}^{\circ}$ and

The standard free energy of sorption $\left(\Delta \mathrm{G}^{\circ}\right)$ was determined using equation (9):

$$
\Delta \mathrm{G}^{\circ}=-\mathrm{RT} \cdot \ln \mathrm{k}_{\mathrm{C}}
$$

and the values of $\mathrm{k}_{\mathrm{C}}$ were expressed according to partition theory:

$$
k_{C}=\frac{Q_{e}}{C_{e}}
$$

The values of $\Delta \mathrm{G}^{\circ}$ were calculated from the experimental results achieved at three different temperatures (293, 303 and $313 \mathrm{~K})$ from equation (11):

$$
\Delta \mathrm{G}^{\circ}=\Delta \mathrm{H}^{\circ}-\mathrm{T} \Delta \mathrm{S}^{\circ}
$$

The negative values of $\Delta \mathrm{G}^{\circ}$ show that the adsorption process is spontaneous and thermodynamically stable [39]. The positive value of $\Delta \mathrm{S}^{\circ}$ reveals that the adsorbent has more affinity towards heavy metal ions and there is increased randomness at solid-liquid interface during the adsorption process [39]. The negative value of $\Delta \mathrm{H}^{\circ}$ indicates that the adsorption process is exothermic in nature [39].

Batch experiments were performed at 20,30 and $40{ }^{\circ} \mathrm{C}$ with $100 \mathrm{mg} / \mathrm{L} \mathrm{Cd}$ (II) initial concentration solutions to predict the nature of $\mathrm{Cd}$ (II) adsorption onto Zeolite-90, Zeolite-110, Zeolite-130 and Zeolite150 and the energetic changes occurring during the process. The thermodynamic parameters such as the standard Gibbs free energy $\left(\Delta \mathrm{G}^{0}\right)$, standard enthalpy changes $\left(\Delta \mathrm{H}^{0}\right)$, and standard entropy changes $\left(\Delta \mathrm{S}^{0}\right)$ were estimated from the plots $\ln K_{C}$ versus $1 / T$ (Figure 11). The slope and intercept of the linear regression were employed to calculate $\Delta \mathrm{S}^{0}$ and $\Delta \mathrm{H}^{0}$, respectively. 


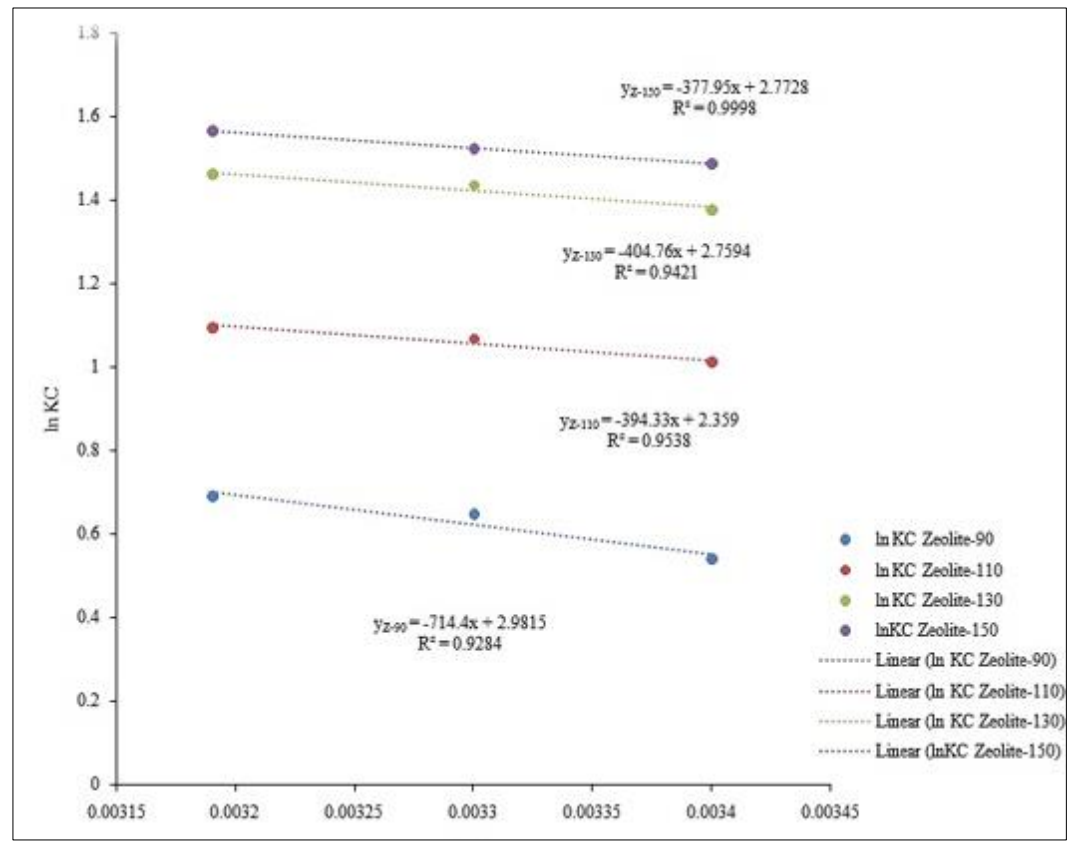

Figure 13. Regressions of Van't Hoff for thermodynamic parameters of $\mathrm{Cd}(\mathrm{II})$ adsorption onto zeolite materials

Table 7. The thermodynamic parameters of the cd(ii) adsorption on zeolites

\begin{tabular}{|c|c|c|c|c|c|}
\hline Adsorbent & $\begin{array}{c}\mathbf{T} \\
\left({ }^{\circ} \mathbf{C}\right)\end{array}$ & $\ln \mathbf{k}_{\mathrm{C}}$ & $\Delta \mathrm{H}^{\circ}\left(\mathrm{kJ} \cdot \mathrm{mol}^{-1}\right)$ & $\Delta \mathrm{S}^{\circ}\left(\mathrm{J} \cdot \mathrm{mol}^{-1} \cdot \mathrm{K}^{-1}\right)$ & $\Delta \mathrm{G}^{\circ}\left(\mathrm{kJ} \cdot \mathrm{mol}^{-1}\right)$ \\
\hline \multirow[t]{3}{*}{ Zeolite-90 } & 20 & 0.5399 & \multirow{3}{*}{5.94} & \multirow{3}{*}{24.79} & -1.32 \\
\hline & 30 & 0.6480 & & & -1.63 \\
\hline & 40 & 0.6911 & & & -1.80 \\
\hline \multirow[t]{3}{*}{ Zeolite-110 } & 20 & 1.0127 & \multirow{3}{*}{3.28} & \multirow{3}{*}{19.61} & -2.47 \\
\hline & 30 & 1.0682 & & & -2.69 \\
\hline & 40 & 1.0960 & & & -2.85 \\
\hline \multirow[t]{3}{*}{ Zeolite-130 } & 20 & 1.3768 & \multirow{3}{*}{3.37} & \multirow{3}{*}{22.94} & -3.35 \\
\hline & 30 & 1.4358 & & & -3.62 \\
\hline & 40 & 1.4624 & & & -3.81 \\
\hline \multirow[t]{3}{*}{ Zeolite-150 } & 20 & 1.4881 & \multirow{3}{*}{3.14} & \multirow{3}{*}{23.05} & -3.63 \\
\hline & 30 & 1.5250 & & & -3.84 \\
\hline & 40 & 1.5674 & & & -4.08 \\
\hline
\end{tabular}

The positive values of $\Delta \mathrm{H}^{0}$ and $\Delta \mathrm{S}^{0}$ (Table 8) show an endothermic sorption process and increasing randomness at the solid-liquid interface during the adsorption of $\mathrm{Cd}(\mathrm{II})$ onto zeolites [39]. A positive value of $\Delta \mathrm{S}^{0}$ implies that the $\mathrm{Cd}(\mathrm{II})$ adsorption process involves a dissociative mechanism [39]. These kinds of adsorption processes are not encouraging at high temperatures [39]. The Gibbs standard energy determined based on Eq. 11 decreased with the temperature for all zeolite samples. The negative $\Delta \mathrm{G}^{0}$ values (Table 7) indicate that $\mathrm{Cd}(\mathrm{II})$ adsorption is spontaneous and thermodynamically favorable [39]. A decrease in the value of $\Delta \mathrm{G}^{0}$ with an increase in temperature (Table 7) indicates that the $\mathrm{Cd}$ (II) adsorption process is more encouraging at higher temperatures. This could be possible because the mobility of $\mathrm{Cd}$ (II) ions in the solution increase with increase in temperature and that the affinity of $\mathrm{Cd}(\mathrm{II})$ on the zeolite surface is higher at high temperatures [39].

\section{Conclusions}

The synthesis of zeolite materials from fly ash an abundant waste from thermal power plant was performed in order to prepare efficient adsorbents for $\mathrm{Cd}(\mathrm{II})$ removal from wastewater. Analyses by means of FT-IR, XRF, and BET surface area measurement indicated that the zeolites synthesized are 
characterized by $\mathrm{Si} / \mathrm{Al}$ ratio between 1.21 and 1.26 , being mainly composed of Na-P1 zeolite. The increase of the temperature of thermal treatment has as result an increase of the specific surface of zeolite materials.

The adsorption of $\mathrm{Cd}(\mathrm{II})$ ions was found to be dependent on $p \mathrm{H}$, adsorbent dose, initial concentration, and contact time. The adsorbed amount of $\mathrm{Cd}(\mathrm{II})$ increased with increasing $p \mathrm{H}$, initial concentration, and contact time till the reaching the equilibrium. The increase of the adsorbent dose has as result a decrease of the adsorption capacity.

Langmuir isotherm displayed a better fitting model than Freundlich isotherm. This indicates that the Cd(II) adsorption occurs on homogeneous zeolite's surface by monolayer sorption. The lowest value of the maximum adsorption capacity determined from Langmuir equation was recorded for Zeolite-90 sample $(126.58 \mathrm{mg} / \mathrm{g})$ and the highest value was calculated for Zeolite-150 sample $(243.90 \mathrm{mg} / \mathrm{g})$. Thus, the increase of the temperature of the fly ash thermal treatment process has as a consequence the increase of the adsorption capacity of the zeolite material prepared. The experimental values of the adsorption capacity are close to maximum adsorption capacity calculated values from Langmuir equation.

The kinetic modelling reveals that the pseudo-second-order model can be used to describe the $\mathrm{Cd}(\mathrm{II})$ sorption onto zeolite materials process. The rate constants for $\mathrm{Cd}(\mathrm{II})$ sorption onto zeolite materials were found to be in the range from $4.5421 \cdot 10^{-4}$ to $1.1978 \cdot 10^{-3} \mathrm{~g} / \mathrm{mg} \cdot \mathrm{min}$ at $20 \pm 2^{\circ} \mathrm{C}$.

The results demonstrate that valuable zeolite materials with high adsorption capacity can be prepared from thermal power plant fly ash through a simple method. The materials prepared can be applied to remediate heavy metals-bearing wastewater.

Acknowledgement. The SEM images obtained on the samples were possible due to EU-funding project POSCCE-A2-O2.2.1-2013-1/Prioritary Axe 2, Project No. 638/12.03.2014, ID 1970, SMIS-CSNR code 48652

\section{References}

1. VAREDA, J.P., VALENTE, A.J.M., DURÃES, L., Journal of Environmental Management 246, 2019, 101-118.

2. VARDHAN, K.H., KUMAR, P.S., PANDA, R.C., Journal of Molecular Liquids 290, 2019, 111197 3. SIMONESCU, C.M., TANASE, I.-R., PURCARU, I.N., TARDEI, C., MARINESCU, V., Rev. Chim., 70(5), 2019, 1758.

4. CUliTA, D.-C., SIMONESCU, C.M., PĂTESCU, R.-E., STANICA, N., Rev. Chim., 69(9), 2018, 2323.

5. BUSUIOC, T.L., SIMONESCU, C.M., NECHIFOR, G., RĂDOI, E., GÎRBEA, I.E., Rev. Chim., 69(6), 2018, 1293.

6. DELEANU C., SIMONESCU C. M., CONSTANTINESCU I., Rev. Chim., 59(6), 2008, 639.

7. SIMONESCU C.M., DINCĂ O.-R., OPREA O., CĂPĂŢÎNĂ C., Rev. Chim., 62 (2), 2011, 183.

8. SIMONESCU C.M., MARIN, I., TARDEI, CH., DRAGNE, M., CĂPĂŢÎNĂ C., Rev. Chim., 65(7), $2014,750$.

9. SIMONESCU C.M., DELEANU C., STANCU M., CĂPĂŢÎNĂ, Journal of Environmental Protection and Ecology 13, no. 2, 2012, p. 462.

10. MELINESCU A., TÂRDEI, C., SIMONESCU C.M., MARINESCU, V., MICLEA, A., Romanian Journal of Materials, (Rev. Rom. Mater.) 43, no. 2, 2013, p. 223.

11. PĂTESCU R.-E., SIMONESCU C.M., NECHIFOR, G., TARDEI, C., IONASCU, C.I., Rev.Chim., 69(4), 2018, 759.

12. PĂTESCU, R.-E., SIMONESCU, C.M., BUSUIOC, L.T., ONOSE, C., MELINESCU, A., Rev. Chim., 67(10), 2016, 1899.

13. CAPATINA C., SIMONESCU, C.M., Environ. Eng. Manag. J. 7, no. 6, 2008, p. 717

14. SIMONESCU C.M., PĂTESCU, R.-E., BUSUIOC, L.T., ONOSE, C., MELINESCU, A., LILEA, V., Rev. Chim., 67(8), 2016, 1498. 
15. ENACHE D.F., VASILE E., SIMONESCU C.M., CULITA D., VASILE E., OPREA O., PANDELE A.M., RAZVAN, A., DUMITRU F., NECHIFOR G., RSC Advances 8, no. 1, 2018, p. 176.

[1616. PATESCU R.E., BUSUIOC L.T., MELINTE I., Rev. Chim., 66(5), 2015, 732.

17. KOSHY, N., SINGH, D.N., J.Environ. Chem. Eng. 4, 2016, p. 1460.

18. BELVISO, C., Prog. Energ Combust. Sci. 65, 2018, p. 109.

http://dx.doi.org/10.1016/j.pecs.2017.10.004

19. MUSYOKA, N.M., PETRIK, L.F., FATOBA, O.O., HUMS, E., Miner. Eng. 53, 2013, p. 9.

20. QUEROL, X., MORENO, N., UMAÑA, J.C., A LASTUEY, A., HERNÁNDEZ, E., LÓPEZSOLER, A., PLANA, F., Int. J. Coal Geology 50, 2002, p. 413.

21. MUSYOKA, N.M., PETRIK, L.F., BALFOUR, G., GITARI, W.M., HUMS, E., J. Environ. Sci. Health Part A 46, 2011, p. 1.

22. LIU, Y., YAN, C., ZHAO, J., ZHANG, Z., WANG, H., ZHOU, S., WU, L., J. Cleaner Prod. 202, 2018, p. 11.

23. KUNECKI, P., PANEK, R., WDOWINA, M., FRANUS, W., Int. J. Miner. Processing 166, 2017, p.69.

24. JIN, X., JI, N., SONG, C., MA, D., YAN, G., LIU, Q., Procedia Eng. 121, 2015, p. 961.

25. ALDAHRI, T., BEHIN,J., KAZEMIAN, H., ROHANI, S., Fuel 182, 2016, p. 494.

26. AHMARUZZAMAN, M., Prog. Energ. Combust. Sci. 36, 2010, p. 327.

27. KUNECKI P., PANEK R., KOTEJA A., FRANUS W., Microporous and Mesoporous Materials 266, 2018, p.102.

28. VISA M., Powder Technology 294, 2016, p. 338-347.

29. IQBAL, A., SATTAR, H., HAIDER, R., MUNIR, S., Journal of Cleaner Production 219, 2019, p. 258.

30. JONES, G.C., JACKSON, B., 2012. Infrared Transmission Spectra of Carbonate Minerals. Springer Science \& Business Media.

31. JEYAGEETHA, C., KUMAR, S.P., International Journal of Science and Research 5(7), 20116, 1688.

32. OMISANYA, N., FOLAYAN, C., AKU, S., ADEFILA, S., Adv. Appl. Sci. Res. 3, 2012, 3746.

33. LI, C., ZHONG, H., WANG, S., XUE, J., ZHANG, Z., Colloids and Surfaces A: Physicochem. Eng. Aspects 470, 2015, p. 258.

34. LTAIEF, O.O., SIFFERT, S., FOURMENTIN, S., BENZINA, M., C. R. Chimie 18, 2015, p. 1123. 35. YOUSEFI, T., YAVARPOUR, S., MOUSAVI, S.H., TORAB-MOSTAEDI, M., DAVARKHAH, R., MOBTAKER, H.G., Proc. Safe Env. Prot. 98, 2015, p. 211.

36. HO, Y.-S., Scientometrics 59 (1), 2004, p. 171.

37. HO, Y.-S., McKAY, G., Trans. Inst. Chem. Eng. 76B, 1998, p. 332.

38. WEBER, W.J., MORRIS, J.C., Proceedings of $1^{\text {st }}$ International Conference on Water Pollution Symposium, vol. 2, Pergamon Press, Oxford, 1962, p. 231.

39. SAHA, P., CHOWDHURY, S., Insight Into Adsorption Thermodynamics, Thermodynamics, Prof. Mizutani Tadashi (Ed.), 2011, ISBN: 978-953-307-544-0, InTech, Available from:

http://www.intechopen.com/books/thermodynamics/insight-into-adsorption-thermodynamics

$\overline{\text { Manuscript received: } 18.12 .2019}$ 